\title{
Three new species of 'tetraphyllidean' cestodes from an undescribed bamboo shark (Orectolobiformes: Hemiscylliidae) in Sri Lanka
}

\author{
Janine N. Caira ${ }^{1}$, Kyle Otto ${ }^{1}$, Daniel Fernando ${ }^{2}$ and Kirsten Jensen ${ }^{3}$ \\ ${ }^{1}$ Department of Ecology \& Evolutionary Biology, University of Connecticut, Storrs, Connecticut, USA; \\ ${ }^{2}$ Blue Resources Trust, Colombo, Sri Lanka; \\ ${ }^{3}$ Department of Ecology \& Evolutionary Biology and the Biodiversity Institute, University of Kansas, Lawrence, Kansas, USA
}

\begin{abstract}
Examination of seven specimens of an undescribed species of bamboo shark (Orectolobiformes: Hemiscylliidae), currently referred to as Chiloscyllium sp. 1, from Sri Lanka yielded three new species of 'tetraphyllidean' cestodes, one each in the genera Carpobothrium Shipley et Hornell, 1906, Spiniloculus Southwell, 1925, and Yorkeria Southwell, 1927. Carpobothrium marjorieae Caira, Otto et Jensen sp. n. differs from its three valid congeners in total length, number of testes, and size of the apical sucker of its anterior bothridial flap. Like Carpobothrium eleanorae Koontz et Caira, 2016 it possesses spherical eggs with highly elongate bipolar filaments, but its eggs are conspicuously larger than those of the latter species. Spiniloculus akshayi Caira, Otto et Jensen sp. n. can be distinguished from its five congeners in total length and number of proglottids. Yorkeria sachiniae Caira, Otto et Jensen sp. n. differs from its 16 congeners in number of proglottids and testes, total length, terminal proglottid, cirrus sac, and cephalic peduncle length, hook size, genital pore position, and bothridial shape. The eggs of Y. sachiniae Caira, Otto et Jensen sp. n. are spindle-shaped and bear a single long, polar filament. All three species were found to exhibit microthrix patterns on their scolices like those of the majority of their congeners that have been examined to date with scanning electron microscopy. Microtriches on the distal surfaces of the bothridial pouches of a species of Carpobothrium were characterised for the first time; C. marjorieae Caira, Otto et Jensen sp. n. was found to possess a modified form of gladiate spinithrix on this surface. Among the seven members of the genus, this is the first species of Chiloscyllium Müller et Henle that has been found to host representatives of all three of these 'tetraphyllidean' genera. However, unlike most of its congeners, a representative of the non-hooked genus Scyphophyllidium Woodland, 1927 was not found infecting Chiloscyllium sp. 1.
\end{abstract}

Keywords: Yorkeria, Carpobothrium, Spiniloculus, Chiloscyllium, carpet shark, Cestoda

The cestodes described herein were discovered during fieldwork, conducted in collaboration with personnel from Blue Resources Trust, in Sri Lanka in March 2018. Among the elasmobranchs examined (see Fernando et al. 2019) were specimens of what appears to be an undescribed species of orectolobiform shark, referred to by Fernando et al. (2019) as Chiloscyllium sp. 1. Necropsy of these specimens yielded material of a new species in each of the 'tetraphyllidean' genera Carpobothrium Shipley et Hornell, 1906, Spiniloculus Southwell, 1925, and Yorkeria Southwell, 1927. All three species are described below, which brings the total number of valid species in each genus to four, six, and 17, respectively.

\section{MATERIALS AND METHODS}

In total, seven shark specimens were examined. All seven were obtained between 10 and 13 March 2018 from fish mar- kets in Vankalai $(08.894167 \mathrm{~N}, 79.928333 \mathrm{E})$ or Point Pedro $(09.828317 \mathrm{~N}, 80.244506 \mathrm{E})$ in the Northern Province of Sri Lanka. Each shark was assigned a unique collection code and number (e.g., SL-65). A series of digital photographs was taken and basic morphometric data were gathered for each specimen. Detailed data for individual sharks are available in the Global Cestode Database (elasmobranchs.tapewormdb.uconn.edu) (Caira et al. 2019) using the collection code and number. The body cavity of each shark was then opened with a mid-ventral incision, and a small sample of liver tissue was removed and preserved in $95 \%$ ethanol for molecular verification of host identities. Sequence data generated for the protein-coding gene $\mathrm{NADH}$ dehydrogenase subunit 2 (NADH2) for six of these seven specimens by Fernando et al. (2019) confirmed the novelty of this shark species which, following these authors, we refer to here as Chiloscyllium sp. 1. The sharks examined consisted of one gravid female (SL-60) $63 \mathrm{~cm}$ in total length (TL), two

Address for correspondence: Janine N. Caira, University of Connecticut, Unit 3043, 75 N. Eagleville Rd., Storrs, Connecticut, 06269-3043, USA. E-mail: janine.caira@uconn.edu

Zoobank number for article: urn:lsid:zoobank.org:pub:3F6F0FC6-316C-4204-A14C-4AD78BA9E414 
immature females (SL-65 and SL-70) $31.4-38.2 \mathrm{~cm}$ in TL, two mature males (SL-31 and SL-59) $68-74.5 \mathrm{~cm}$ in TL, and three immature males (SL-32, SL-66 and SL-71) $39.8-55.6 \mathrm{~cm}$ in TL.

In each case, the spiral intestine was removed and opened with a longitudinal mid-ventral incision. In three cases, the spiral intestine was fixed in a whirl-pack bag with $10 \%$ seawater buffered formalin $(9: 1)$ and shaken for approximately $30 \mathrm{~s}$ for morphological work. In one case, the spiral intestine was placed in $95 \%$ ethanol for molecular work. In the remaining three cases, the spiral intestine was cut in half along its length, and one half was fixed for morphological work and the other for molecular work. Molecular sequence data generated for the species described herein are forthcoming as part of a larger study.

Tapeworms were prepared as whole mounts for light microscopy as follows. They were hydrated in a graded ethanol series, stained in Delafield's hematoxylin, differentiated in tap water, destained in acidic 70\% ethanol, neutralised in a basic $70 \%$ ethanol, dehydrated in a graded ethanol series, cleared in methyl salicylate, and mounted on glass slides in Canada balsam. Drawings were made using a camera lucida mounted on a Zeiss Axioskop 2 compound microscope. Measurements and images were taken using a SPOT Diagnostic Instrument digital camera system mounted on a Zeiss Axioskop 2 compound microscope and SPOT software (version 4.5). Measurements are given in the text as ranges followed in parentheses by the mean, standard deviation, number of specimens measured, and number of measurements made when more than one measurement was taken per specimen. All measurements are in micrometres unless otherwise noted. Measurements of features of attached proglottids were taken only from terminal mature proglottids.

Specimens were prepared for examination with scanning electron microscopy (SEM) as follows. They were hydrated in a graded filtered ethanol series, transferred to distilled water, post-fixed in $1 \%$ osmium tetroxide overnight, dehydrated in a graded filtered ethanol series, transferred to hexamethyldisilizane (HMDS) for approximately $30 \mathrm{~min}$ and, after removal of the bulk of the HMDS, were allowed to air dry in a fume hood. They were then mounted on aluminium stubs with double-sided carbon tabs, sputter coated with approximately $35 \mathrm{~nm}$ of gold-palladium, and examined with an FEI Nova Nano 450 field emission scanning electron microscope. Microthrix terminology follows Chervy (2009). Shape terminology follows Clopton (2004). Hook measurements follow Caira et al. (2007).

Semi-permanent mounts of eggs were prepared as follows. Detached gravid proglottids were placed in a 1:1 mixture of $70 \%$ ethanol and glycerine overnight. Proglottids were subsequently broken open with insect pins, the eggs isolated and mounted in that same solution on a glass slide under a cover slip, and twice ringed with nail polish. Images were taken with the microscope and camera system described above for measurements.

Museum abbreviations are as follows: BRT-P, Blue Resources Trust, Parasitology Collection, Kalkudah, Eastern Province, Sri Lanka; LRP, Lawrence R. Penner Parasitology Collection, University of Connecticut, Storrs, Connecticut, USA; USNM, National Museum of Natural History, Smithsonian Department of Invertebrate Zoology, Washington, D.C., USA.

\section{RESULTS}

Carpobothrium marjorieae Caira, Otto et Jensen sp. n. Figs. 1, 2, 3A

ZooBank number for species: urn:1sid:zoobank.org:act: 52AA6F9F-0E94-4E9B-A58E-C3F590804371

Description (based on whole mounts of ten mature worms, four detached mature proglottids, two detached gravid proglottids, and four scolices prepared for SEM): Worms euapolytic, $4.5-7.5 \mathrm{~mm}(6.1 \pm 1.2 ; 10)$ long; 17-37 $(25 \pm 6 ; 9)$ proglottids per worm. Scolex consisting of 4 obovoid, stalked bothridia and inconspicuous cephalic peduncle (Figs. 1A, 2A). Bothridia with large central pouch and small anterior and posterior flaps; bothridial pouch 162-430 (228 $\pm 71 ; 8 ; 26)$ long, 174-344 (275 $\pm 43 ; 10$; 37 ) wide, with robust bundles of horizontal musculature at anterior and posterior margins; anterior flap obcordate, 45-60 (53 $\pm 11 ; 2 ; 2)$ long, 115-128 (122 $\pm 9 ; 2 ; 2)$ wide, bearing small sucker on anterior-medial margin; sucker 15-16 (15 $\pm 1 ; 2 ; 2)$ long, $14(2 ; 2)$ wide (Fig. 1A); posterior flap shallowly obovoid, 46-100 (70 $\pm 20 ; 9 ; 5)$ long, 95-166 (125 \pm 27 ; 5; 9) wide; both flaps retractable into pouch (Fig. 2A); stalks muscular, 55-279 (114 \pm 55 ; 9; 25) long, 79-134 (103 $\pm 20 ; 3 ; 7)$ wide.

Distal surface of bothridial pouch with somewhat small, sparsely arranged slightly blunt gladiate spinitriches and acicular filitriches (Fig. 2B); distal surfaces of anterior and posterior bothridial flaps not observed. Proximal surface of anterior and posterior bothridial flaps (Fig. 2C) and bothridial pouch adjacent to flaps with densely arranged spathulate spinitriches, proximal surface near base of bothridial pouch with densely arranged gladiate spinitriches (Fig. 2D), filitriches not observed on either surface. Stalks with densely arranged spathulate spinitriches and capilliform filitriches anteriorly (Fig. 2E); spinitriches becoming smaller and more sparse posteriorly (Fig. 2F), entirely lacking from posterior-most regions of stalk (Fig. 2G). Strobilar surface with capilliform filitriches arranged in broad scutes (Fig. 2H).

Proglottids acraspedote. Immature proglottids 16-36 $(25 \pm 6$; 9) in number, wider than long, becoming longer than wide with maturity (Fig. 1B). Attached mature proglottids 1 in number; terminal proglottid 762-1,695 (1,067 \pm 296 ; 9) long, 170-339 (257 \pm 61 ; 9) wide; detached mature proglottids $2,359-4,113(3,108 \pm 739 ; 4)$ long, 473$587(538 \pm 53 ; 4)$ wide (Fig. 1C).

Testes 44-57 (51 $\pm 5 ; 8)$ in number, oval, 14-50 (25 \pm 8 ; 9; 31) long, 30-108 (55 \pm 17 ; 9; 31) wide in terminal proglottid, 53-68 (59 $\pm 5 ; 2 ; 6)$ long, 88-138 (110 $\pm 18 ; 2 ; 6)$ wide in detached mature proglottids, arranged in 4-6 irregular columns, extending from anterior margin of proglottid to anterior margin of cirrus sac, 1 layer deep in cross section. Cirrus sac J-shaped, 190-313 (259 $\pm 48 ; 8)$ long, 48-95 (64 $\pm 16 ; 8)$ wide in terminal proglottid, 520-700 (610 \pm 127 ; 2 ; 2) long, 100-168 (134 $\pm 48 ; 2$; 2) wide in detached mature proglottids. Vas deferens narrow, coiled, extending anterolateral and posterior to cirrus sac, entering cirrus sac at 



Fig. 1. Line drawings of Carpobothrium marjorieae Caira, Otto et Jensen sp. n. from Chiloscyllium sp. 1 (sensu Fernando et al. 2019). A - scolex (holotype; BRT-P 0001), arrowhead indicates sucker; B - whole worm (paratype; USNM 1638642); C - detached mature proglottid, dorsal view (paratype; LRP 10318); D - detail of ovary and ootype (paratype; LRP 10318). 


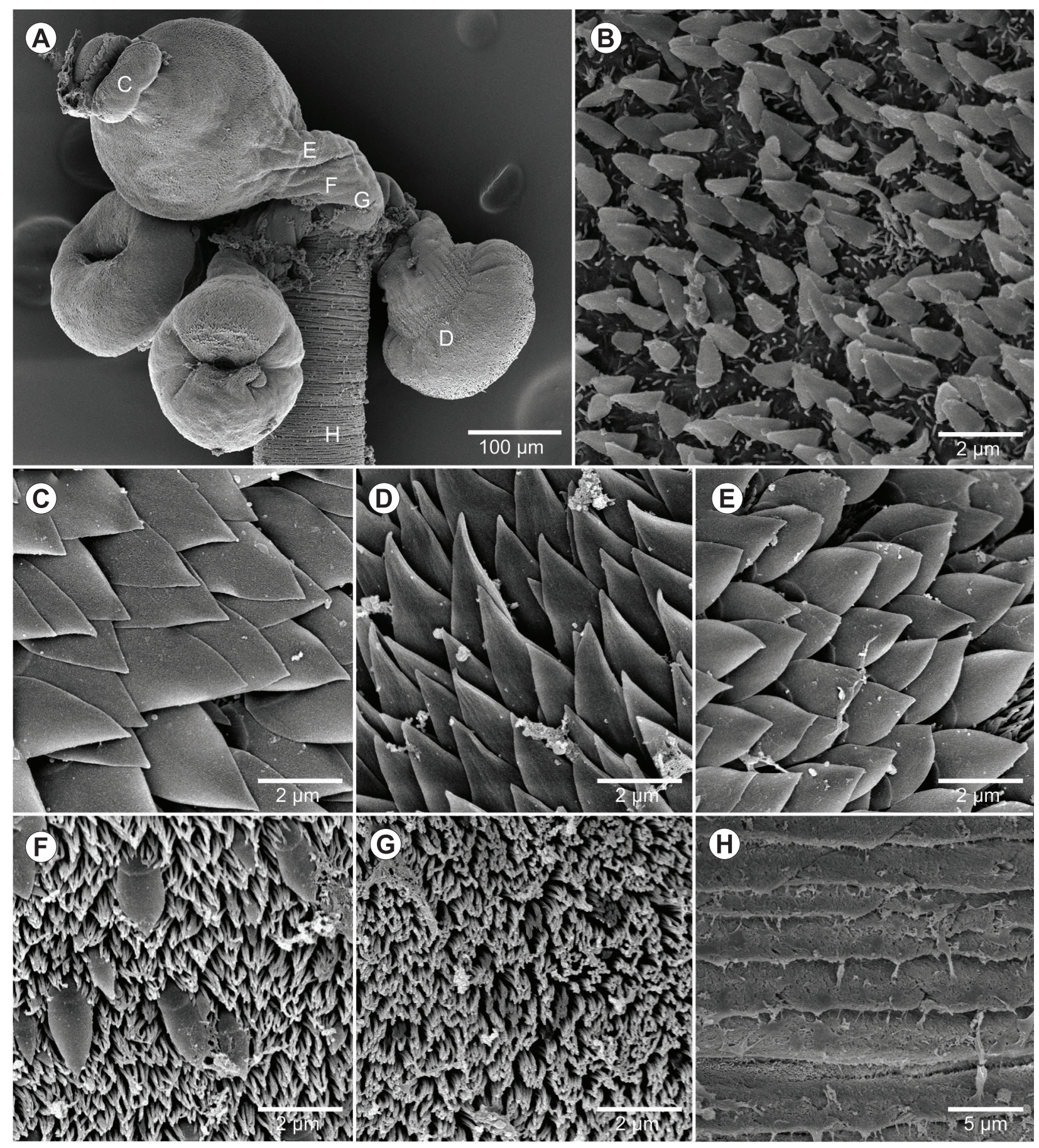

Fig. 2. Scanning electron micrographs of Carpobothrium marjorieae Caira, Otto et Jensen sp. n. from Chiloscyllium sp. (sensu Fernando et al. 2019). A - scolex; B - distal surface of bothridial pouch (imaged on specimen in which bothridial pouch was mechanically disrupted to reveal this surface); C - proximal surface of bothridial flap; D - proximal surface of bothridial pouch near base; $\mathbf{E}$ - anterior surface of bothridial stalk; F - mid-surface of bothridial stalk; $\mathbf{G}$ - posterior surface of bothridial stalk; $\mathbf{H}$ - strobilar surface.

anteromedial margin. Internal and external seminal vesicles not observed. Genital pores lateral, irregularly alternating, opening $45-59 \%(53 \pm 5 ; 9)$ of proglottid length from posterior end in terminal proglottid, opening 46-62\% (54.5 \pm 7 ; 4) from posterior end in detached mature proglottids.

Ovary posterior in position, weakly $\mathrm{H}$-shaped in frontal view (Fig. 1D), symmetrical, 59-225 (106 \pm 53 ; 8) long, $48-131(95 \pm 27 ; 8)$ wide in terminal proglottid, $178-450$ $(273 \pm 153 ; 3)$ long, $183-320(249 \pm 69 ; 3)$ wide in detached mature proglottids, tetralobed in cross section; ovarian margins lobulated; ovarian bridge near anterior margin of ovary. Mehlis' gland at posterior margin of ovary. Vagina extending along medial line of proglottid anteriorly from ootype region initially as narrow, sinuous duct, expanding into extensive seminal receptacle, narrowing at posterior margin of cirrus sac, then extending to anterior margin of cirrus sac and then laterally to open into common genital atrium anterior to cirrus sac.

Vitellarium follicular; follicles in 2 lateral bands; each band consisting of multiple, irregular, loosely arranged columns of 

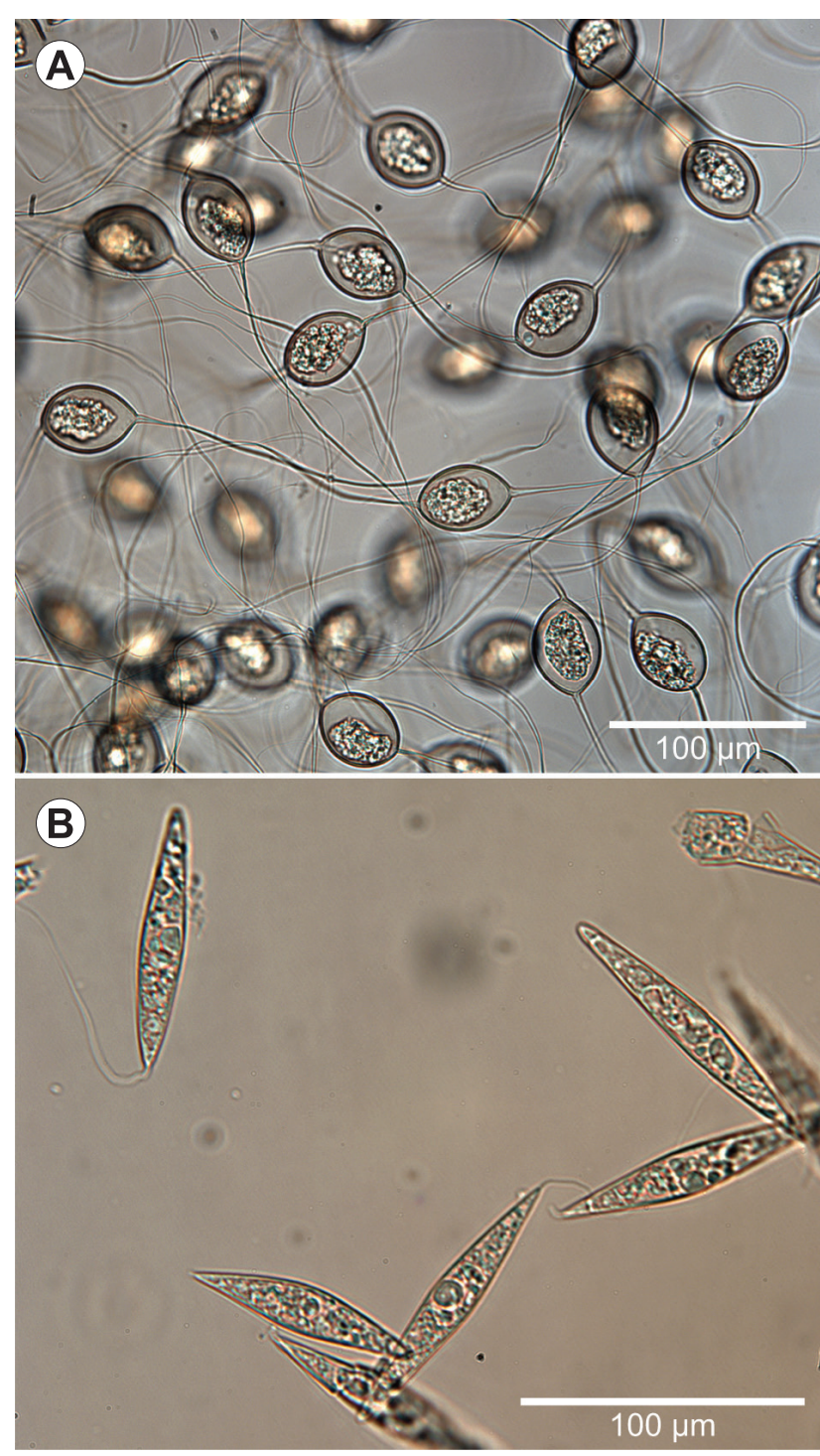

Fig. 3. Light micrographs of eggs from detached, gravid proglottids. A - Carpobothrium marjorieae Caira, Otto et Jensen sp. n.; B - Yorkeria sachiniae Caira, Otto et Jensen sp. n.

follicles, extending from near anterior region of proglottid to posterior margin of proglottid, uninterrupted by terminal genitalia and ovary, converging medially in postovarian region; vitelline follicles $15-34(10 \pm 2 ; 9 ; 34)$ long, 17-50 (26 \pm 8 ; 9; 34) wide in terminal proglottid, 20-65 (37 $\pm 15 ; 3$; 9) long, $42.5-115(65 \pm 26 ; 3 ; 9)$ wide in detached mature proglottids. Uterus saccate, extending from ootype along medial line of proglottid to posterior margin of cirrus sac, ventral to vagina; uterine duct entering uterus near its anterior margin. Excretory ducts 4 , arranged in 1 dorsal and 1 ventral lateral pair. Eggs spheroid, 62-66 (63 $\pm 2 ; 2 ; 10)$ long, $48(2 ; 10)$ wide, with highly elongate bipolar filaments (Fig. 3A).

Type host: Chiloscyllium sp. 1 (sensu Fernando et al. 2019).

Ty p e loc a lity: Indian Ocean, Gulf of Mannar, off Vankalai (08.894167N, 79.928333E), Northern Province, Sri Lanka.

Additional locality: None.

Site of infection: Spiral intestine.

Prevale nce : 5 of 7 specimens examined (71\%).
Type material: Holotype (BRT-P 0001); seven paratypes (five whole worms and two detached mature proglottids; USNM 1638641-1638647); six paratypes (four whole worms and two detached mature proglottids; LRP 10314-10319) and four SEM vouchers (LRP 10320-10323). Scolices examined with SEM retained in J.N. Caira's personal collection.

Etymology: This species honours KO's late great-grandmother, Marjorie Varcoe, for encouraging his inquiry into and exploration of the natural world.

Remarks. Following Koontz and Caira (2016), the concept of Carpobothrium embraced here is restricted to species reported from bamboo sharks. Although the appropriate generic home for species reported from batoids that were originally assigned to Carpobothrium remains to be determined, the morphological differences between these taxa and those parasitising bamboo sharks articulated by Koontz and Caira (2016) make it clear that they are inconsistent with the genus as it was originally circumscribed by Shipley and Hornell (1906). As a consequence, the description of $C$. marjorieae Caira, Otto et Jensen sp.n. brings the total number of valid species in the genus (see Caira et al. 2017) to four.

This new species is a smaller worm than Carpobothrium megaphallum Subhapradha, 1955 (4.5-7.5 mm vs. $12 \mathrm{~mm}$ in total length); it also possesses fewer proglottids than this species (17-37 vs. 47). Carpobothrium marjorieae has fewer testes (44-57 vs. 60-67) and a conspicuously longer terminal proglottid (762-1,695 vs. 87-302) than Carpobothrium chiloscyllii Shipley et Hornell, 1906 as redescribed by Koontz and Caira (2016). It most closely resembles Carpobothrium eleanorae Koontz et Caira, 2016 but differs from this species in bearing a smaller sucker on the anterior flap (15-16 long by 14 wide vs. 20-27 long by $23-25$ wide). In addition, based on measurements made from the five eggs of $C$. eleanorae that are in focus in fig. 6A of Koontz and Caira (2016), while similar in shape, the eggs of $C$. marjorieae are much longer and wider than those of $C$. eleanorae (62-65 by 48 vs. $37-43$ by 29-31), excluding the bipolar filaments.

By breaking open the bothridial pouch of a specimen prepared for SEM and then recoating the specimen with gold/palladium, we were able to investigate the microtriches on the distal surface of the pouch for a species of Carpobothrium for the first time (Fig. 2B). Although the filitriches are clearly acicular in form, the spinitriches represent a modified version of gladiate spinithrix. These spinitriches taper distally, but they do not come to a full point, instead they terminate somewhat bluntly and thus we have referred to these microtriches as blunt gladiate spinitriches (Fig. 2B).

\section{Spiniloculus akshayi Caira, Otto et Jensen sp. n.}

Figs. 4, 5

ZooBank number for species:

urn:lsid:zoobank.org:act: BCBB46A0-E1C7-4BE6-AF3E-89D67C8CD6C3

Description (based on whole mounts of two mature worms, four immature worms [scolex measurements only], and scolices of three immature specimens examined with SEM): Worms euapolytic, 5.5-6.1 mm (5.8 $\pm 0.4 ; 2)$ long; 

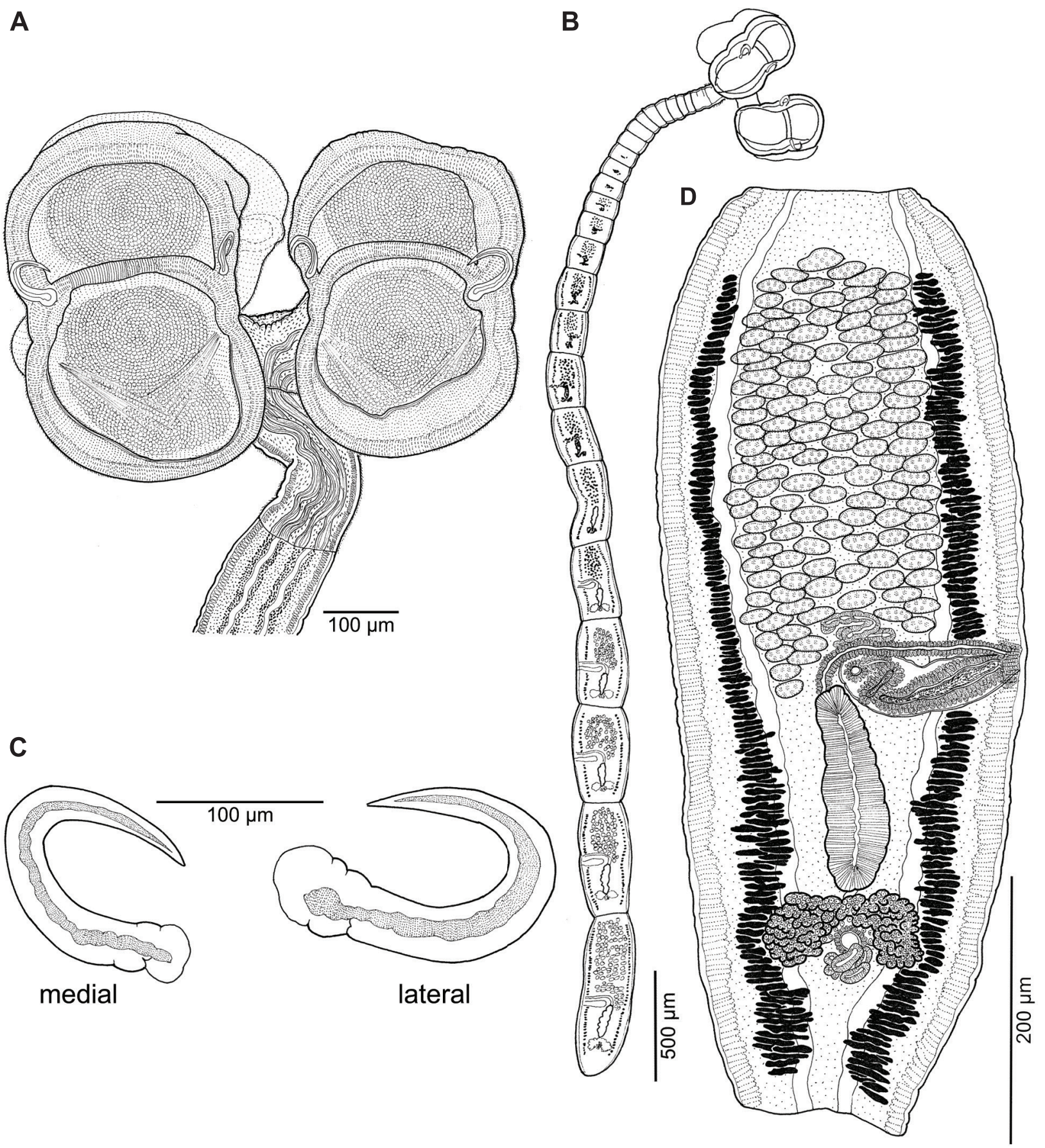

Fig. 4. Line drawings of Spiniloculus akshayi Caira, Otto et Jensen sp. n. from Chiloscyllium sp. 1 (sensu Fernando et al. 2019). A - scolex (paratype; USNM 1638634); B - whole worm (holotype; BRT-P 0002); C - hooks (holotype; BRT-P 0002); D - mature proglottid, ventral view (paratype; USNM 1638634).

25-27 $(26 \pm 1 ; 2)$ proglottids per worm. Scolex consisting 2 pairs of bothridia and cephalic peduncle. Bothridia fused in back-to-back pairs; each bothridial pair borne on pedicel (Figs. 4A, 5A); bothridium 362-476 (408 \pm 36 ; 6; 11) long, with 1 pre-hook loculus, 1 pair of uni-pronged hooks, and 1 post-hook loculus; post-hook loculus with weak transverse muscle bundles posterior to midlevel. Pre-hook loculus 139-184 (158 $\pm 14 ; 6$; 12) long, 220-310 (275 $\pm 29 ; 6 ; 11)$ wide. Post-hook loculus 207-288 (248 $\pm 28 ; 6$; 11) long, 221-307 (282 $\pm 24 ; 6 ; 12)$ wide. Pedicels 80-190 (142 \pm 37 ; 7; 4) long, 88-155 (106 $\pm 21 ; 5 ; 9)$ wide. Cephalic pedun- cle 84-194 (123 $\pm 49 ; 5)$ long, 95-133 (109 \pm 16 ; 5) wide. Scolex with 4 coiled muscle bundles extending from posterior margin of scolex proper to anterior margin of strobila, 2 muscle bundles extending through each pedicel to attach to proximal surface of each bothridium in a pair. Hooks yellow, hollow, C-shaped, oriented anteriorly, prongs usually facing one another, of approximate equal curvature, lateral hook slightly larger than medial hook (Fig. 4C). Medial hook 51-73 (62 $\pm 8 ; 5 ; 8)$ long, 39-50 (45 $\pm 4 ; 6 ; 8)$ wide; prong maximum thickness $12-16(14 \pm 2 ; 5 ; 7)$. Lateral 


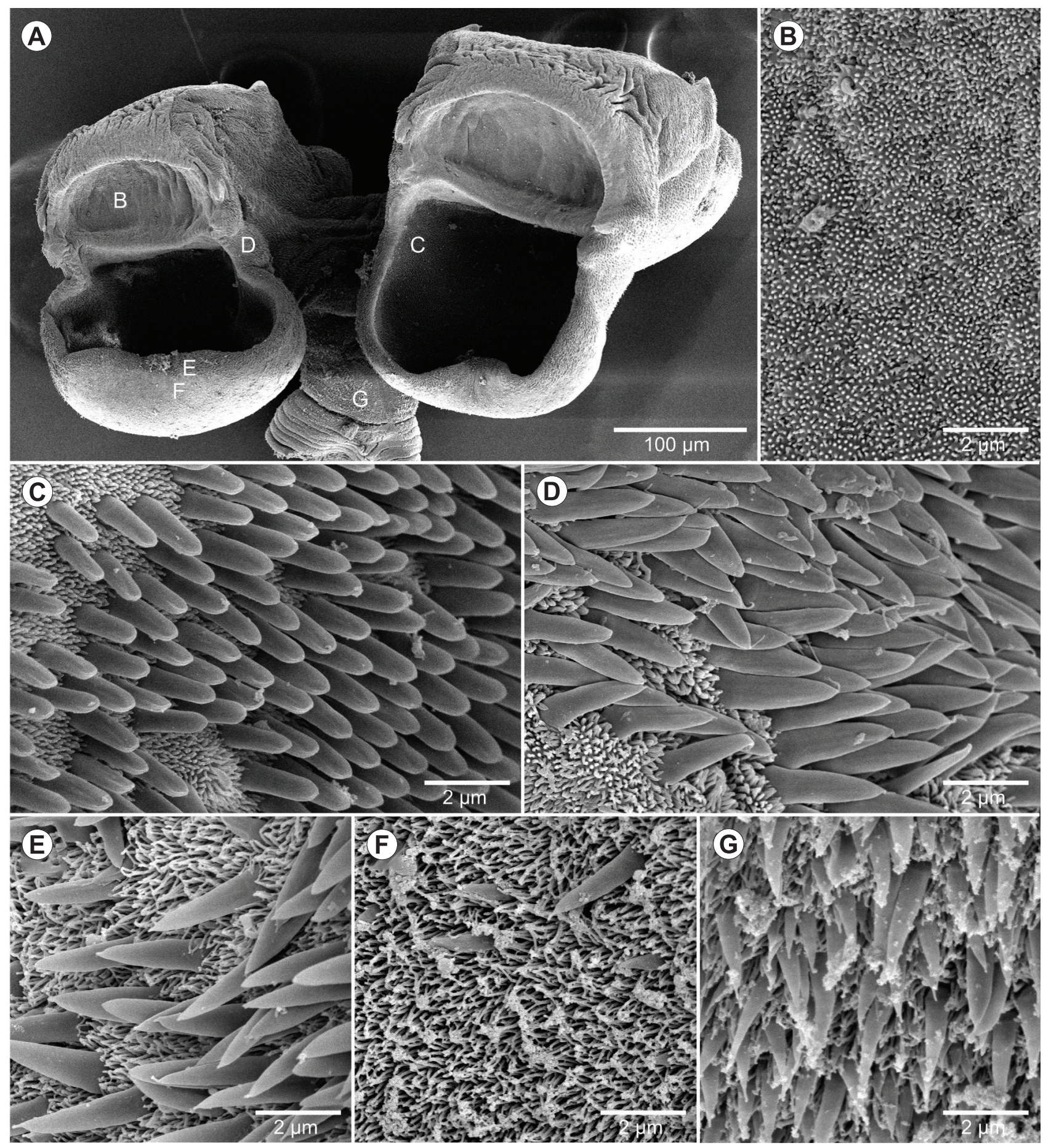

Fig. 5. Scanning electron micrographs of Spiniloculus akshayi Caira, Otto et Jensen sp. n. from Chiloscyllium sp. 1 (sensu Fernando et al. 2019). A - scolex; B - distal surface of pre-hook loculus; C - distal surface of post-hook loculus; D - proximal surface of bothridium at anterior region of post-hook loculus; $\mathbf{E}$ - proximal surface of posterior region of bothridium near rim; $\mathbf{F}$ - proximal surface of posterior region of bothridium away from rim; $\mathbf{G}$ - surface of cephalic peduncle.

hook 67-84 (75 $\pm 6 ; 5 ; 8)$ long, 49-57 $(53 \pm 3 ; 5 ; 8)$ wide, prong maximum thickness $14-18(16 \pm 2 ; 5 ; 8)$.

Distal surface of pre-hook loculus with papilliform filitriches (Fig. 5B). Distal surface of post-hook loculus with lingulate spinitriches interspersed with acicular filitriches (Fig. 5C). Proximal surface of bothridium at anterior region of post-hook loculus with aristate gladiate spinitriches interspersed with acicular filitriches (Fig. 5D); spinitriches more sparsely distributed on posterior proximal bothridi- al surfaces (Fig. 5E,F). Surfaces of pedicels and cephalic peduncle (Fig. 5G) with aristate gladiate spinitriches interspersed with capilliform filitriches.

Proglottids acraspedote. Immature proglottids wider than long, becoming longer than wide with maturity (Fig. 4B). Mature proglottids $1(\mathrm{n}=2)$ in number, 755-936 (846 \pm 128 ; 2) long, 236-288 (262 \pm 37 ; 2) wide, length to width ratio $2.6-3.9(3.3 \pm 0.9 ; 2): 1$. 
Testes $93-124(112 \pm 14 ; 2 ; 4)$ in number, oval, 11-19 (15 $\pm 2 ; 2 ; 8)$ long, 28-37 $(33 \pm 3 ; 2 ; 8)$ wide, arranged in 5-6 irregular preporal columns, 1 layer deep; postporal testes absent (Fig. 4D). Cirrus sac elongate oval, 137-140 (139 $\pm 2 ; 2)$ long, 42-51 (47 \pm 6 ; 2) wide, containing coiled cirrus; cirrus covered with small spinitriches. Vas deferens minimal, arranged in relatively few small coils at anteromedial margin of cirrus sac, entering cirrus sac at anteromedial margin. Internal and external seminal vesicles lacking. Genital pores lateral, irregularly alternating along length of strobila, $47-50 \%(48 \pm 2 ; 2)$ of proglottid length from posterior margin of proglottid.

Ovary in posterior quarter of proglottid, approaching inverted U-shaped in frontal view, symmetrical, 55-63 (59 \pm 6; 2) long, 117-127 (122 \pm 7 ; 2) wide, tetralobed in cross section; ovarian margins lobulated; ovarian bridge near anterior margin of ovary. Mehlis' gland at posterior margin of ovary. Vagina essentially straight, extending anteriorly from ootype region along midline of proglottid, then laterally along anterior margin of cirrus sac, opening into common genital atrium anterior to cirrus sac.

Vitellarium follicular; follicles in 2 lateral bands; each band consisting of 1 dorsal and 1 ventral column, extending from near anterior margin of testicular field to posterior margin of proglottid, interrupted by terminal genitalia, uninterrupted by ovary. Uterus saccate, extending from ovarian isthmus along medial line of proglottid to middle of cirrus sac, ventral to vagina; uterine duct not observed. Excretory ducts 4 , arranged in 1 dorsal and 1 ventral lateral pair. Gravid proglottids not observed.

Type host: Chiloscyllium sp. 1 (sensu Fernando et al. 2019). Ty p e 1 o c a lity: Indian Ocean, off Point Pedro (09.828317N, 80.244506E), Northern Province, Sri Lanka.

Additional locality: None.

Site of infection: Spiral intestine.

Prevalence: 1 of 7 specimens examined (14\%).

Type materia 1: Holotype (BRT-P 0002); three paratypes (one mature and two immature worms; USNM 1638634-1638636); two paratypes (immature worms; LRP 10309, 10310) and three SEM vouchers (LRP 10311-10313). Scolices examined with SEM retained in J.N. Caira's personal collection.

E t y m o log y: This species honours our colleague Akshay Tanna from Blue Resources Trust for his expert assistance with the logistics of our brief, but highly productive, collecting trip to Sri Lanka.

Remarks. This brings the total number of valid species of Spiniloculus to six. Spiniloculus akshayi Caira, Otto et Jensen sp. n. is easily distinguished from all five of its congeners in size and number of proglottids. It is smaller in total length than Spiniloculus calhouni Desjardins et Caira, 2011, Spiniloculus mavensis Southwell, 1925 as redescribed by Desjardins and Caira (2011), and Spiniloculus ratnagiriensis (Deshmukh et Shinde, 1980) Desjardins and Caira (2011) (5.5-6.1 mm vs. 11.1-18.8 mm, 11.6-34.2 $\mathrm{mm}, 12-14 \mathrm{~mm}$, respectively) and is greater in total length than Spiniloculus paigeae Desjardins et Caira, 2011 (5.5$6.1 \mathrm{~mm}$ vs. $2.5-5 \mathrm{~mm}$ ). It possesses more proglottids than Spiniloculus fylerae Desjardins et Caira, 2011 and S. paigeae
(25-27 vs. 17-23 and 10-21, respectively) and further differs from S. calhouni, S. mavensis, and S. ratnagiriensis in possessing fewer proglottids (25-27 vs. 71-106, 37-57, and about 35 , respectively).

\section{Yorkeria sachiniae Caira, Otto et Jensen sp. n.}

Figs. 3B, 6, 7

ZooBank number for species:

urn:lsid:zoobank.org:act: 6AA1BB41-DE91-47EB-B524-A6F8D089A726

Description (based on whole mounts of eight mature worms, one detached gravid proglottid, and the strobilar voucher of one specimen prepared for SEM, and three scolices prepared for SEM): Worms euapolytic, 7.8-13.3 $\mathrm{mm}(10.6 \pm 2 ; 8)$ long; $53-59(57 \pm 2 ; 8)$ proglottids per worm. Scolex consisting of 2 pairs of bothridia and cephalic peduncle. Bothridia fused in back-to-back pairs, each bothridial pair born on pedicel (Figs. 6A, 7A); bothridium 312-506 (394 $\pm 54 ; 7 ; 27)$ long, with specialised anterior pre-hook region in form of shallow loculus, 1 pair of unipronged hooks, and undivided post-hook loculus. Pre-hook loculus 103-178 (141 \pm 19 ; 7; 17) long, 195-293 (261 \pm $28 ; 7 ; 23)$ wide. Post-hook loculus 213-341 (283 $\pm 32 ; 7$; 24) long, 319-378 (350 $\pm 17, \mathrm{n}=5, n=17)$ wide. Pedicels 145-689 (353 $\pm 170 ; 7 ; 13)$ long, 97-158 (132 $\pm 19 ; 7 ; 13)$ wide. Cephalic peduncle 100-209 (142 $\pm 46 ; 7)$ long, 104 $144(121 \pm 13 ; 7)$ wide. Scolex with 4 conspicuous coiled muscle bundles; each bundle extending from proximal surface of bothridium through pedicle to posterior margin of peduncle. Hooks yellow, hollow, C-shaped, oriented anteriorly, with prongs facing away from one another, with bases embedded in posterolateral and posteromedial margins of pre-hook loculus; medial and lateral hooks conspicuously dissimilar in size (Fig. 6C). Medial hook 225-257 (244 \pm 10 ; 7; 28) long, 94-146 (122 $\pm 15 ; 7 ; 27)$ wide; prong maximum thickness $39-44(42 \pm 2 ; 2 ; 6)$. Lateral hook $87-121$ (105 $\pm 10 ; 6 ; 15)$ long, 41-78 (56 $\pm 11 ; 5 ; 12)$ wide; prong maximum thickness $18-19(19 \pm 1 ; 2 ; 4)$.

Distal surface of pre-hook loculus and anterior region of post-hook loculus (Fig. 7B) covered with acicular filitriches. Distal surface of remainder of post-hook loculus covered with lingulate spinitriches and acicular filitriches (Fig. 7C). Proximal bothridial surfaces covered with large, essentially gladiate spinitriches and acicular filitriches (Fig. 7D). Anterior regions of pedicels covered with densely arranged gladiate to spathulate spinitriches and acicular filitriches (Fig. 7E); more posterior regions covered with broadly spathulate spinitriches and acicular filitriches (Fig. 7F). Cephalic peduncle covered with spathulate spinitriches and acicular filitriches (Fig. 7G).

Proglottids acraspedote; anterior-most regions of proglottids with spinitriches. Immature proglottids 49-56 (53 $\pm 2 ; 8$ ) in number, wider than long, becoming longer than wide with maturity (Fig. 6B). Mature proglottids 3-5 (4 $\pm 1 ; 8)$ in number; terminal mature proglottid 666-1,109 (824 \pm 124 ; 9) long, 335-597 (433 \pm 78 ; 9) wide, length to width ratio $1.7-2: 3(1.9 \pm 0.2 ; 9)$.

Testes 35-70 (60 $\pm 10 ; 9)$ in number, oval, 25-43 (33 \pm 5 ; 9; 29) long, 35-95 (65 $\pm 12 ; 9 ; 29)$ wide, arranged in 4-5 irregular preporal columns, extending from near ante- 
A

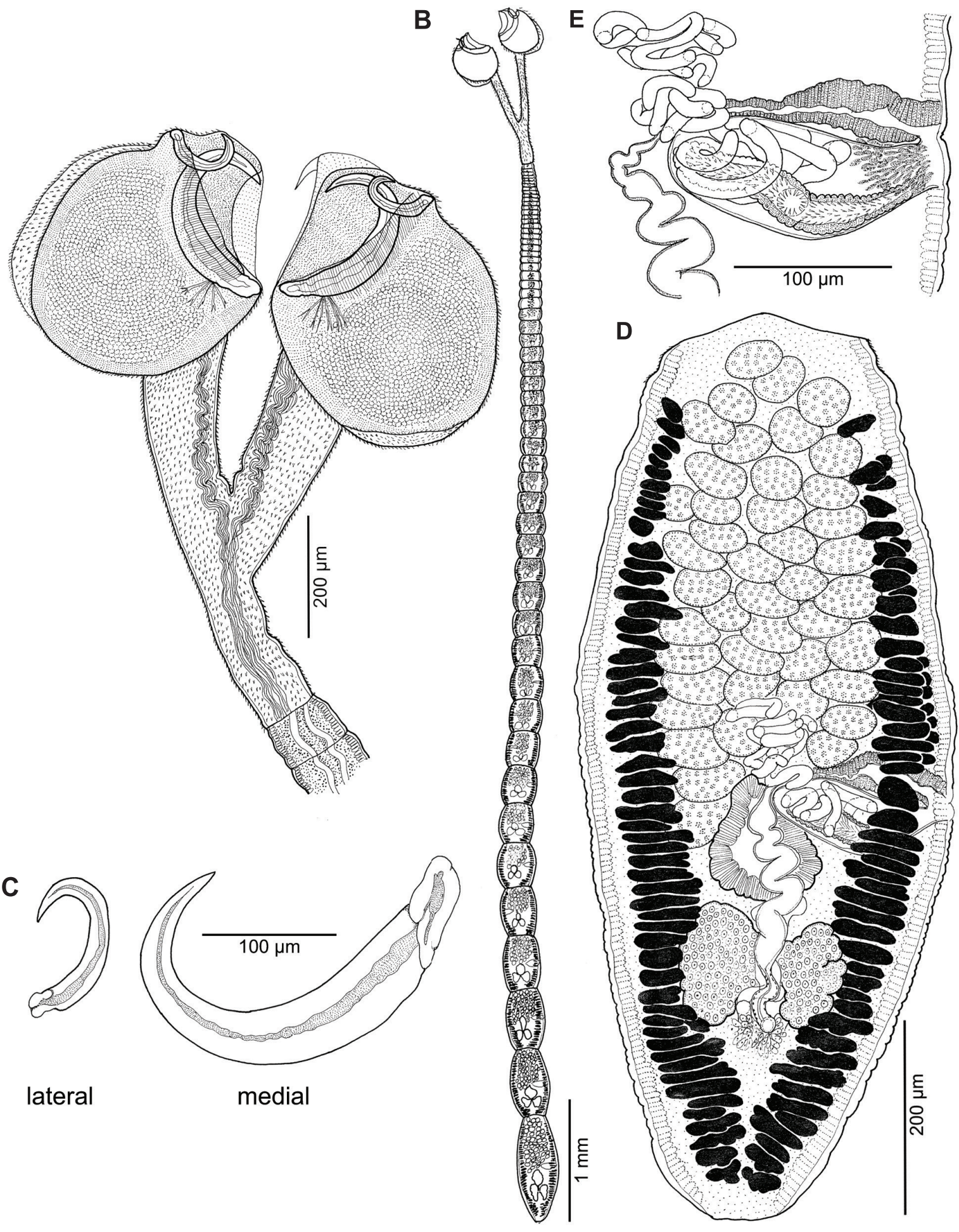

Fig. 6. Line drawings of Yorkeria sachiniae Caira, Otto et Jensen sp. n. from Chiloscyllium sp. 1 (sensu Fernando et al. 2019). A - scolex (holotype; BRT-P 0003); B - whole worm (paratype; USNM 1638638); C - hooks (holotype; BRT-P 0003); D - terminal proglottid, dorsal view (paratype; USNM 1638638); E - terminal genitalia (paratype; USNM 1638638).

rior margin of proglottid to level of genital pore (Fig. 6D), 1 layer deep; postporal testes absent. Cirrus sac elongate oval, 167-245 (199 \pm 24 ; 9) long, 36-71 (52 \pm 11 ; 9) wide, containing coiled cirrus; cirrus armed with spinitriches. Vas deferens medial, coiled, arranged at anteromedial margin of cirrus sac, entering anteromedial margin of cirrus sac. Internal and external seminal vesicles lacking. Genital pores lateral, irregularly alternating, $47-55 \%(52 \pm 3 ; 9)$ of proglottid length from posterior margin of proglottid.

Ovary in posterior third of proglottid, essentially H-shaped in frontal view, symmetrical, 92-131 (109 \pm 14 ; 9) long, 137-217 (177 \pm 26 ; 9) wide, tetralobed in cross section; ovarian margins weakly lobulated; ovarian bridge near anterior margin of ovary. Mehlis' gland at posterior 


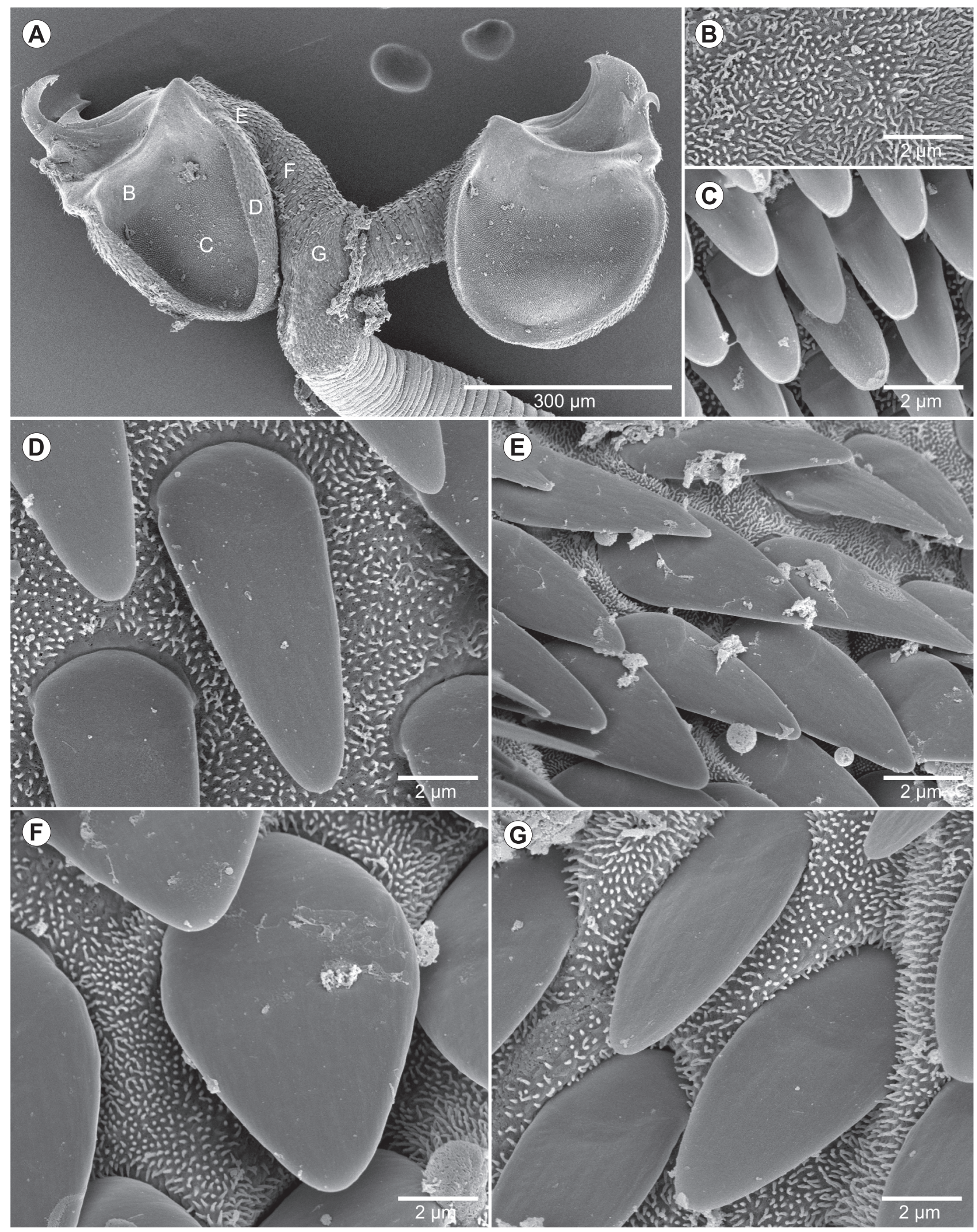

Fig. 7. Scanning electron micrographs of Yorkeria sachiniae Caira, Otto et Jensen sp. n. from Chiloscyllium sp. 1 (sensu Fernando et al. 2019). A - scolex; B - distal surface of anterior region of post-hook loculus; C - distal surface at mid-level of post-hook loculus; $\mathbf{D}$ - proximal surface of bothridium; $\mathbf{E}$ - proximal surface of anterior region of pedicel; $\mathbf{F}$ - proximal surface of mid-region of pedicel; G - surface of cephalic peduncle. 
margin of ovary, conspicuous. Vagina sinuous, extending anteriorly from ootype region along midline of proglottid, then laterally along anterior margin of cirrus sac to open into common genital pore anterior to cirrus sac (Fig. 6E).

Vitellarium follicular; follicles in 2 lateral bands; each band consisting of 2 dorsal and 2 ventral columns; columns extending from approximately second row of testes to posterior margin of proglottid, uninterrupted by terminal genitalia or ovary, converging medially posterior to ovary; follicles in posterior half of proglottid conspicuously wider than those in anterior half. Uterus saccate, extending from anterior margin of ovary along medial line of proglottid to anterior margin of cirrus sac, ventral to vagina; uterine duct not observed. Excretory ducts 4, arranged in 1 dorsal and 1 ventral lateral pair. Eggs spindle-shaped, 83-128 (102 \pm $14 ; 2$; 10) long, 16-21 (17 $\pm 2 ; 2 ; 10)$ wide, with single, long polar filament (Fig. 3B).

Type host: Chiloscyllium sp. 1 (sensu Fernando et al. 2019).

Type 1 oc a lity: Indian Ocean, off Point Pedro (09.828317N, 80.244506E), Northern Province, Sri Lanka.

Additional locality: None.

Site of infection: Spiral intestine.

Prevalence: 5 of 7 specimens examined (71\%).

Type material: Holotype (BRT-P 0003); four paratypes (USNM 1638637-1638640); three paratypes (LRP 10287, 10306, 10307) and SEM voucher (LRP 10308). Scolices examined with SEM retained in J.N. Caira's personal collection.

Etymology: This species honours Sachini Welikannage for her assistance with the preparation of many of the whole mounts examined in this study.

Remarks. This new species differs from its 16 congeners as follows. It possesses a greater number of proglottids than Yorkeria chiloscyllii Shinde, Mohekar et Jadhav, 1986, Yorkeria hilli Caira et Tracey, 2002, Yorkeria kelleyae Caira et Tracey, 2002, Yorkeria longstaffae Caira, Jensen et Rajan, 2007, Yorkeria moretonensis Cutmore, Cribb, Bennett et Beveridge, 2018, Yorkeria pusillulus Caira, Jensen et Rajan, 2007, Yorkeria teeveeyi Caira, Jensen et Rajan, 2007, Yorkeria williamsi Cutmore, Cribb, Bennett et Beveridge, 2018, and Yorkeria yubodohensis Caira, Jensen et Rajan, 2007 (53-59 vs. 30-40, 13-19, 4-8, 16-22, 18, 7-9, $32-38,38$, and 22-43, respectively).

Furthermore, Yorkeria sachiniae Caira, Otto et Jensen sp. n. is greater in total length than $Y$. hilli, Y. kelleyae, $Y$. longstaffae, Y. pusillulus, and Y. williamsi $(7.8-13.3 \mathrm{~mm}$ vs. $2.2-5 \mathrm{~mm}, 1.4-3.5 \mathrm{~mm}, 1.5-2.4 \mathrm{~mm}, 1.2-2.2 \mathrm{~mm}$, and 5.8-7.6 mm, respectively). It can be further distinguished from $Y$. moretonensis and $Y$. teeveeyi by its shorter terminal proglottid length (666-1,109 vs. 1,237-2,286 and 1,120 1,315 , respectively). It differs further from $Y$. chiloscylli in its possession of a longer cirrus sac (167-245 vs. 100-150). In addition to having a greater total length than Yorkeria saliputium Caira, Jensen et Rajan, 2007 (7.8-13.3 mm vs. $1.4-2.8 \mathrm{~mm})$, the new species possesses medial hooks that are greater than, rather than less than, twice as long as the lateral hooks (medial hooks 225-257 and lateral hooks 87-121 vs. medial hooks 97-107 and lateral hook 57-70).
Yorkeria sachiniae can be distinguished from Yorkeria chonburiensis Purivirojkul et Boonsoong, 2012 in its possession of fewer proglottids (53-59 vs. 118-168) and a genital pore that is more anterior in position (47-55\% vs. 29-34\% of total length from posterior margin of proglottid). It differs from Yorkeria xiamenensis Li et Wang, 2006 in its possession of shorter medial (225-257 vs. 433-458) and lateral (87-121 vs. 198-220) hooks, and also a considerably shorter terminal proglottid (666-1,109 vs. 2,570-4,111). The new species has a greater number of proglottids (53-59 vs. 30-40) and fewer testes (42-70 vs. 90-95) than Yorkeria southwelli Deshmukh, 1979 and is greater in total length $(7.8-13.3 \mathrm{~mm} v s .5 .4-6.0 \mathrm{~mm})$ and in terminal proglottid length (666-1,109 vs. 470-487) than Yorkeria garneri Caira, Jensen et Rajan, 2007.

The most conspicuous difference between $Y$. sachiniae and Yorkeria izardi Caira, Jensen et Rajan, 2007 involves the shape of the bothridia, and specifically the post-hook loculi. Whereas those of the former are essentially round (213-34 long by 319-378 wide), the post-hook loculi of $Y$. izardi taper posteriorly and are longer than wide (218-433 long by $193-266$ wide). The new species most closely resembles Yorkeria parva Southwell, 1927 as redescribed by Caira et al. (2007). However, Yorkeria sashiniae has a shorter cephalic peduncle (100-209 vs. 321-587) and a longer cirrus sac (167-245 vs. 115-155) than Y. parva.

\section{DISCUSSION}

The cestode fauna found in the spiral intestine of Chiloscyllium sp. 1 is consistent in several respects with those of other species of bamboo sharks. To date, as many as 11 species of Chiloscyllium Müller et Henle have been recognised, three of which have not yet been formally described (i.e., Chiloscyllium cf. punctatum Müller et Henle sensu Naylor et al. 2012; Chiloscyllium cf. arabicum Gubanov sensu White et al. 2006; and Chiloscyllium sp. 1 sensu Fernando et al. 2019). Seven of these 11 species have been examined for cestodes. Among these, four have been reported to be parasitised by species of both Yorkeria and Carpobothrium. Chiloscyllium griseum Müller et Henle hosts Yorkeria chiloscyllii (see Shinde et al. 1986) and Carpobothrium megaphallum (see Subhapradha 1955); Chiloscyllium hasseltii Bleeker hosts Yorkeria garneri (see Caira et al. 2007) and Carpobothrium eleanorae (see Koontz and Caira 2016); Chiloscyllium indicum (Gmelin) hosts Yorkeria parva and Yorkeria teeveeyi (see Southwell 1927 and Caira et al. 2007, respectively) and Carpobothrium chiloscyllii (see Shipley and Hornell 1906). However, Chiloscyllium sp. 1 is the first member of its genus reported to host a species of Carpobothrium, Spiniloculus, and Yorkeria. Furthermore, although the non-hooked genus Schyphophyllium Woodland, 1927 (recently determined to be the senior synonym of Orectolobicestus Ruhnke, Caira et Carpenter, 2006 by Caira et al. 2020) is often a member of the cestode community of species of Chiloscyllium, having been reported in C. griseum, C. hasseltii, C. indicum, C. punctatum, and C. cf. punctatum (see Ruhnke et al. 2006), we found no evidence of this genus in Chiloscyllium sp. 1. Admittedly, our sample size of only seven sharks is 
relatively low and the lack of representation of this genus may merely be an artefact of small sample size.

The microthrix patterns seen in all three species on surfaces that could be examined are generally consistent with those reported for their congeners for which SEM data are available. Most conspicuously, like C. eleanorae and C. chiloscyllii (see Koontz and Caira 2016), Carpobothrium marjorieae bears spathulate spinitriches on most of its proximal bothridial surfaces. The discovery of an unusual form of gladiate spinithrix on the distal surfaces of the bothridial pouches of C. marjorieae requires verification in other species before this can be considered a feature of the genus. Like its four congeners that have been examined with SEM (i.e., Spiniloculus calhouni, S. fyler$a e, S$. mavensis, and $S$. paigeae) (see Desjardins and Caira 2011, Cutmore et al. 2018), S. akshayi bears aristate gladiate spinitriches on its proximal bothridial surfaces and pedicels, and lingulate spinitriches on its distal surfaces. Among its congeners, the microthrix pattern seen in Yorkeria sachiniae most closely resembles those described for Y. hilli by Caira and Tracy (2002), for Y. garneri, Y. izardi, Y. longstaffae, Y. parva, Y. pusillulus, Y. saliputium, Y. teeveeyi, and Y. yubodohensis by Caira et al. (2007), and for Y. williamsi by Cutmore et al. (2018) in the lack of spinitriches on the distal surface of the pre-hook loculus, the presence of lingulate spinitriches on the distal bothridial surface of the post-hook loculus, and the presence of spathulate or gladiate spinitriches on the proximal surfaces of the bothridia, pedicels, and cephalic peduncle. In these respects, Y. sachiniae differs from Yorkeria kelleyae and Yorkeria moretonensis, both of which bear aristate gladiate spinitriches on the latter surfaces (see Caira and Tracey 2002, Cutmore et al. 2018).

Koontz and Caira (2016) were the first to describe the morphology of the eggs of a species of both Carpobothrium and Yorkeria, in that case from C. hasseltii. Our results for the species in both genera found parasitising Chiloscyllium sp. 1, while differing somewhat in size, are fully consistent morphologically with their species, suggesting that these morphologies may be conserved at the generic level. The eggs of both C. eleanorae and C. marjorieae are spherical and bear extremely long bipolar filaments. In contrast, those of the unidentified species of Yorkeria reported on by Koontz and Caira (2016) and Y. sachiniae are spindleshaped and bear only a single polar filament. Although the identities of the first intermediate host of species of Carpobothrium and Yorkeria remain unknown - beyond the typical generalisation for elasmobranch cestodes that it is likely to be some sort of copepod (see Jensen and Bullard 2010) - the fact that eggs of both taxa are somewhat buoyant even in ethanol, suggests the filaments may serve to increase the time the eggs remain in the water column, increasing the changes of transmission.

The phylogenetic placements of all three new species among their congeners remain to be determined. Moreover, larger systematic issues surround each of the genera. The phylogenetic results of Cutmore et al. (2018) based on partial 28S sequence data failed to recover a monophyletic Yorkeria relative to Spiniloculus. Furthermore, the phylogenetic position of Carpobothrium among elasmobranch tapeworms is unclear based on analyses of existing molecular markers (Caira et al. 2014, 2017). Resolution of these phylogenetic issues will require a more comprehensive approach using denser taxon sampling and additional loci.

Finally, some discussion of the justification for describing three new species from a host species that has not yet been formally described is in order. Over the past several decades, our collections have led to the discovery of tens of new species of elasmobranchs. Many of these species were originally recognised based on their unique $\mathrm{NADH} 2$ sequence signatures (Naylor et al. 2012). Although a number have since been formally described, the descriptions of elasmobranchs often lag behind those of their parasites. To stabilise the identities of undescribed hosts from which parasites have been collected, and also to help advance work describing these elasmobranchs, we have typically assigned each a unique number, deposited the $N A D H 2$ sequence data in GenBank, and generated a series of digital images of the species. In the case of Chiloscyllium sp. 1, that information is provided in Fernando et al. (2019).

Acknowledgements. Collection of the hosts examined here would not have been possible without the expert field assistance of Rosalind Bown, Akshay Tanna and Ramajeyam Gobiraj of Blue Resources Trust. We are grateful to the Tokyo Cement Group for institutional support to the Blue Resources Trust. Collections were conducted under a letter of no objection (as species were not protected under national law and were from dead fisheries specimens) with reference number WL/3/2/74/17, dated 4 January 2018, issued by the Department of Wildlife Conservation (DWC), Sri Lanka. Samples were exported under a letter of no objection with reference number WL/3/2/74/17, dated 14 March 2018, also issued by the DWC. This work was supported by funds from NSF DEB awards 1457762, 1457776, 1921404, and 1921411. Any opinions, findings and conclusions or recommendations expressed in this material are those of the authors and do not necessarily reflect the views of the National Science Foundation.

\section{REFERENCES}

Caira J.N., Jensen K., Barbeau E. (Eds.) 2019: Global Cestode Database. World Wide Web electronic publication, www.tapewormdb.uconn.edu

Caira J.N., Jensen K., Hayes C., Ruhnke T.R. 2020: Insights from new cestodes of the crocodile shark, Pseudocarcharias $k a-$ moharai (Lamniformes: Pseudocarchariidae), prompt expansion of Scyphyophyllidum and formal synonymization of seven phyllobothriidean genera - at last! J. Helminthol. 94: e132.
Caira J.N., Jensen K., Rajan C. 2007: Seven new Yorkeria species (Cestoda: Tetraphyllidea) from Borneo and Australia and their implications for identification of Chiloscyllium (Elasmobranchii: Orectolobiformes) species. J. Parasitol. 93: 357-376.

Caira J.N., Jensen K., Ruhnke T.R. 2017: “Tetraphyllidea” van Beneden, 1849 relics. In: J.N. Caira and K. Jensen (Eds.), Planetary Biodiversity Inventory (2008-2017): Tapeworms from Vertebrate Bowels of the Earth. University of Kansas, Natural 
History Museum, Special Publication No. 25, Lawrence, pp. 371-400.

Caira J.N., Jensen K., Waeschenbach A., Olson P.D., LitTLEwOOD D.T.J. 2014: Orders out of chaos-molecular phylogenetics reveals the complexity of shark and stingray tapeworm relationships. Intl. J. Parasit. 44: 55-73.

Caira J.N., TraCy R. 2002: Two new species of Yorkeria (Tetraphyllidea: Onchobothriidae) from Chiloscyllium punctatum (Elasmobranchii: Hemiscylliidae) in Thailand. J. Parasitol. 88: $1172-1180$.

Chervy L. 2009: Unified terminology for cestode microtriches: a proposal from the International Workshops on Cestode Systematics in 2002-2008. Folia Parasitol. 56: 199-230.

Clopton R.E. 2004: Standard nomenclature and metrics of plane shapes for use in gregarine taxonomy. Comp. Parasitol. 71: 130140.

Cutmore S.C., CribB T.H., Bennett M.B., Beveridge I. 2018 Tetraphyllidean and onchoproteocephalidean cestodes of elasmobranchs from Moreton Bay, Australia: description of two new species and new records for seven described species. Syst. Parasitol. 95: 807-827.

Desjardins L., Caira J.N. 2011: Three new species of Spiniloculus (Cestoda: Tetraphyllidea) from Chiloscyllium punctatum (Elasmobranchii: Orectolobiformes) off Borneo with clarification of the identity of the type of the genus. Folia Parasitol. 58: $55-68$.

Fernando D., Bown R.M.K., Tanna A., Gobiraj R., Ralicki H., Jockusch E.L., Ebert D.A., Jensen K., Caira J.N. 2019: New insights into the identities of the elasmobranch fauna of Sri Lanka. Zootaxa 4585: 201-238.

Jensen K., Bullard S.A. 2010: Characterization of a diversity of tetraphyllidean and rhinebothriidean cestode larval types, with comments on host associations and life-cycles. Int. J. Parasitol. 40: 889-910.

Koontz A., Caira J.N. 2016: Emendation of Carpobothrium ("Tetraphyllidea") from bamboosharks (Orectolobiformes: Hemiscyliidae) with redescription of Carpobothrium chiloscyllii and description of a new species from Borneo. Comp. Parasitol. 83: 149-161.

Naylor G.J.P., Caira J.N., Jensen K., Rosana K.A.M., White W.T., LAST P.R. 2012: A DNA sequence-based approach to the identification of shark and ray species and its implications for global elasmobranch diversity and parasitology. Bull. Am. Mus. Nat. Hist. 367: 1-262.

Ruhnke T.R., Caira J.N., Carpenter S.D. 2006: Orectolobicestus n. g. (Cestoda: Tetraphyllidea), with the description of five new species and the transfer of Phyllobothrium chiloscyllii to the new genus. Syst. Parasitol. 65: 215-233.

Shinde G.B., MoheKar A.D., Jadhav B.V. 1986: Yorkeria chiloscyllii sp. n. (Cestoda: Tetraphyllidea) from Chiloscyllium griseum (marine fish - family Scylliidae) from the west coast of India. Helminthologia 23: 257-260.

Shipley A.E., Hornell J. 1906: Report on the cestode and nematode parasites from the marine fishes of Ceylon. Report to the Government of Ceylon on the Pearl Oyster Fisheries of the Gulf of Manaar (Herdman), Part V: 43-96.

Southwell T. 1927: On a collection of cestodes from marine fishes of Ceylon and India. Ann. Trop. Med. Parasitol. 21: 351-373.

Subhapradha C.K. 1955: Cestode parasites of fishes of Madras Coast. Ind. J. Helminthol. 7: 41-132.

White W.T., Last P.R., Stevens J.D., Yearsley G.K., Fahmi, DHARMADI. 2006: Economically Important Sharks and Rays of Indonesia. Australian Centre for International Agricultural Research, Canberra, 329 pp.

Cite this article as: Caira J.N., Otto K., Fernando D., Jensen K. 2021: Three new species of 'tetraphyllidean' cestodes from an undescribed bamboo shark (Orectolobiformes: Hemiscylliidae) in Sri Lanka. Folia Parasitol. 68: 004. 